\title{
Training-Effectiveness and Team-Performance in Public Organization
}

\author{
Akmal UMAR ${ }^{1}$, Hasmin TAMSAH ${ }^{2}$, M. MATTALATTA ${ }^{3}$, B. BAHARUDDIN ${ }^{4}$, Abdul LATIEF R ${ }^{5}$ \\ Received: August 01, 2020 Revised: October 05, 2020 Accepted: October 15, 2020
}

\begin{abstract}
This study aims to invest in empirical relationships in a model that becomes the process of Team-Performance due to participation in practical training through causality between Training Effectiveness variables, soft-skill competence, Employee-Creativity, and team performance. This study uses a quantitative approach. The analytical tool used is structural equation modeling (SEM) using AMOS version 23 software. Accidental sampling technique is used to collect the sample. As many as 202 respondents filled up a survey questionnaire with complete and valid answers. This study's results significantly contribute to fill the gap of inadequate empirical evidence that can answer critical questions about the missing link between training and employee-performance, more specifically between training-effectiveness and teamperformance. The results showed that practical training would encourage employees' soft-skill competence, improve Employee-Creativity, and improve Team-Performance. Furthermore, training-effectiveness also plays a significant role in enhancing employee-creativity and helping in optimal team-performance. This study also found that the relationship between employee-creativity and team-performance did not show positive and significant results; therefore, empirically, it did not support the hypothesis built in this study. Practical training targeted towards increasing soft-skills and creativity is a fundamental reason which not only aims to contribute toward organizational performance but also provides personal feedback for self-development.
\end{abstract}

Keywords: Soft-skill Competence, Training-Effectiveness, Employee-Creativity, Team-Performance

JEL Classification Code: J24, J28, O15

\section{Introduction}

A person's ability to think and act for any given activity is limited, therefore to improve performance, which leads to significant performance improvement in any organization, each team member's synergy is needed (Akob et al., 2020; Mappamiring et al., 2020). In many cases, both in private

${ }^{1}$ First Author and Corresponding Author. Associate Professor, Department of Management, Sekolah Tinggi IImu Manajemen Indonesia, Makassar, Indonesia [Postal Address: Bung-Street, Tamalanrea, Makassar City, South Sulawesi, Indonesia]

Email: muh.umar.akmal@gmail.com

${ }^{2}$ Associate Professor, Department of Management, STIE AMKOP, Makassar, Indonesia

${ }^{3}$ Full Professor, Department of Management, STIE AMKOP, Makassar, Indonesia

${ }^{4}$ Associate Professor, Department of Management, STIE AMKOP, Makassar, Indonesia

${ }^{5}$ Associate Professor, Department of Management, STIE AMKOP, Makassar, Indonesia

(c) Copyright: The Author(s)

This is an Open Access article distributed under the terms of the Creative Commons Attribution Non-Commercial License (https://creativecommons.org/licenses/by-nc/4.0/) which permits unrestricted non-commercial use, distribution, and reproduction in any medium, provided the original work is properly cited. and public organizations, there are many failures due to the team's collapse working incorrectly, which impacts team performance (Haerani et al., 2020; lestari et al., 2020; Mansur et al., 2019). Therefore, various skills are needed, such as soft skills, competence, and creativity to better the team performance. For an organization to achieve its goals, it needs a reliable team performance. We all know that an organization consists of a collection of people with different abilities, it takes a common perception and synergy in building concepts that leads to achieving a particular goal (Meiyani \& Putra, 2019; Firman et al., 2020; Mappamiring et al., 2020). If the team members can work in a synergy and work together well, it will create a great impact on achieving results that are in line with the organizational goals (Firman et al., 2020; Arfah \& Putra, 2019). Public organizations which aim to provide quality services to the community require collective performance. Let's take an example of a police institution, here apart from the individual competence and creativity at work, team performance is equally important. The police works in units or teams, requiring the maximum performance of each of these units to support the police organization's performance as a whole. The Police of the Republic of Indonesia requires competent members and 
high creativity at work so they are expected to encourage the performance of the team and the organization as a whole. The series of training, competence, and creativity that leads to team performance can be seen with the human capital theory approach.

The Human capital theory emphasizes that there is an intangible asset in an organization that is very much needed to improve employee performance or work productivity, which can enhance organizational performance (Bontis et al., 2007; Mention \& Bontis employee to be more, 2012). Human capital consists of individual capability, individual motivation, the organization climate, workgroup effectiveness, and leadership (Mayo, 2000). There is still a view that the human capital theory has not explained social resource problems as a whole and considers human capital theory to have limitations. But there are problems even with this theory (e.g., Fix, 2018; Marginson, 2019; Firman et al., 2020). Another view finds that human capital theory has implications for the development of the education system (Almendarez, 2013; Dong \& Phuong, 2018; Laurens \& Putra, 2020; Sangha et al., 2019) where human capital focuses on skills and all individual characteristics of employees, become assets for the company which increases productivity (Tan, 2014; Zamora, 2007).

The present research was carried out with the above mentioned viewpoints. Several studies have shown that training can improve performance (Appiah, 2010; Asfaw et al., 2015; Neyestani, 2014; Eduardo-Salas et al., 2008). However, researchers did not find adequate references on how Training-Effectiveness improves soft competence or increases Employee-Creativity and how soft-skill competence increases Employee-Creativity. With relation to this, the study seeks to fill in the lack of references that can link the study variables. This study develops a model by utilizing several existing references to reconstruct the relationship between practical training and soft skill competence, which will further increase Employee-Creativity and will lead to the achievement of the final goal for improving the team performance. On the other hand, Training-Effectiveness can directly encourage Employee-Creativity and TeamPerformance.

\section{Literature Review}

\subsection{Theoretical Background and Hypothesis Development}

Most of the training is carried out in private organizations as well as in public organizations. Most of the training for public organizations is provided at the expense of the state. Only practical training can really help in attaining the set goals. Training-Effectiveness can encourage improvement in employee attitudes (Sahinidis \& Bouris, 2008) where practical training can provide changes in employees' skills, knowledge, and attitudes (Swart et al., 2005). Besides that, it can also increase motivation, high commitment, and increased job satisfaction (Aboyassin \& Sultan, 2017; Sahinidis \& Bouris, 2008). Meanwhile, soft-skill competence can be measured by searching for information, orientation on efficiency, systematic planning, problemsolving, and persuasive ability (Chou et al., 2010; Riyanti et al., 2016; Daud et al., 2012). Practical training can encourage employee competency improvement in public organizations, where the quality of the human resources is essential in achieving employee and organizational success (Appiah, 2010). On the other hand, practical training can encourage employee competency improvement, namely increased knowledge and skills. (Asfaw et al., 2015; Ikram et al., 2019). The effectiveness of training carried out by an organization can be of benefit to the individual which can facilitate the application of training results on the job (Inn et al., 2010) then increased motivation and competence can encourage employee creativity (Scaduto et al., 2008; Scott et al., 2004; Surbaini, 2018).

The effectiveness of training in this study is measured by indicators of additional knowledge, ability to remember, and the ability to refer to the surveys. (e.g., Perdue et al., 2002; Wilson et al., 2002). Training-Effectiveness can also encourage improvement in team performance (Eduardo Salas et al., 2008), There is a cause and effect relationship between practical training and performance because someone who has attended practical training will have the ability to encourage cohesiveness, and improve team performance. Besides, practical training, cross-training, will also promote increased teamwork and as a result, it will also enhance the performance of the team (Blickensderfer et al., 2004; Marks et al., 2002). Increasing the knowledge of someone who has attended training or sharing knowledge on the training results will help understand the work in detail to work as a team (Hendrawan et al., 2018; Jamshed et al., 2018). He also added that the ability to apply the training results, such as training that leads to increased social skills, can encourage a person's sense of belonging to their social environment (Kiliç \& Aytar, 2017; Weidmann \& Deming, 2020). The training, especially for a long duration, can improve teamwork and a transactive memory system because it builds communication among trainees (Salman \& Hassan, 2015). This situation will increase the effectiveness of teamwork, which in turn can encourage improvement in team performance (Lewis, 2004).

Training-Effectiveness in this study is measured by indicators of additional knowledge, ability to remember, and ability to practice (Perdue et al., 2002; Wilson et al., 2002). Soft-skill competence is measured by referring to research (e.g., Spencer \& Spencer, 1993; Chou et al., 2010; Dwi Riyanti et al., 2016; Salina Daud et al., 2012), such us: searching for information, orientation on efficiency, 
Akmal UMAR, Hasmin TAMSAH, M. MATTALATTA, B. BAHARUDDIN, Abdul LATIEF R /

Journal of Asian Finance, Economics and Business Vol 7 No 11 (2020) 1021-1031

systematic planning, problem-solving, and the persuasive ability. Therefore, a description of the literature then leads us to the following hypothesis:

H1: Training-Effectiveness has a positive effect on soft skill competence

H2: Training-Effectiveness has a positive effect on Employee-Creativity

H3: Training-Effectiveness has a positive effect on TeamPerformance

Soft-skill competence which is characterized by searching for information, orientation towards efficiency, systematic planning, problem-solving, and the persuasive ability (Chou et al., 2010; Riyanti et al., 2016; Daud et al., 2012). Soft skills are very important in making an employee more energetic at work; Soft skills are also believed to promote employee creativity related to work. A creative employee certainly has more abilities, especially in terms of finding additional information to increase competence. Creativity will also make employees skilled, especially in doing systematic planning. Besides that, the high level of creativity will trigger employees' ability to solve problems accurately and with proper measurement. One important element of invention is the ability to negotiate various work problems faced by employees; This helps an employee to calm down at work because a good mood and positive thoughts can enhance an employee's performance improvement (George \& Zhou, 2007). Furthermore, individual differences, the interaction of contextual factors, and individual differences can also affect employee creativity (Zhou \& Shalley, 2003).

An employee who is motivated to work, either because of the expectations of rewards or just because of suggestions for improvements to what he has done, will encourage their creativity (Juniper, 1996) Furthermore, there are four dimensions of human resources, including personal characteristics, namely learning/training of content knowledge, creative process skills, motivation, creative self-efficacy, and personality that can increase employee creativity (Joo et al., 2013; Lee et al., 2012; Qureshi, 2016). Liu et al (2017) found that a performance-oriented human resource system can encourage employee creativity, and further employee creativity can encourage team performance improvement. Someone who has skills related to creativity, such as political skills, can face uncertain situations (Salas et al., 1995; Choi et al., 2010) and is able to control the situation with a change of mindset and good personality (e.g., Edwards et al., 2006; Hecht \& Allen, 2009; Peeters et al., 2006); They always want to excel by competing or working together, these factors can increase team performance (Beersma et al., 2003). Employee-Creativity in this study is measured by indicators of creativity-related skills, encountering ambiguity, locus of control, and need for achievement (Beheshtifar \& Zare, 2013; M., 2008). Furthermore, to measure Team-Performance, namely the indicators contributing to the team's work, interacting with teammates, keeping the team on track, expecting quality, having relevant knowledge, skills, and abilities (Hwang, 2018) are required. Furthermore, the following hypotheses can be formulated:

H4: Soft skill competence has a positive effect on Employee-Creativity

H5: Employee-Creativity has a positive effect on TeamPerformance

\section{Research Methods and Materials}

\subsection{Sample Criteria}

The sample in this study consisted of 202 people who were all male police officers in the Regional Police (POLDA) of South and West Sulawesi, Indonesia; with a sample distribution of 54 people $(26.7 \%)$, with the position of Police Brigadier (BRIGPOL), 47 men (23.2\%) came from the position as Chief Police Brigadier (BRIPKA), 39 men $(19.3 \%)$ came from the role as Second Police Inspector (AIPDA), 37 men (18.3\%) came from the role as Adjunct Police Inspector (AIPTU), 28 men (13.8\%) came from the role as First Police Inspector (IPTU), 8 men (0.39\%) came from the role as adjunct police commissioner (AKP), 3 men $(0.14 \%)$ came from the role as senior police commissioner (AKBP), 3 men $(0.14 \%)$ came from the role as police commissioner (KOMPOL), 3 men $(0.14 \%)$ came from the role as Senior Commissioner (KOMBES). The dominant respondents are in the age range of 30- 51 years, as much as $85 \%$. The rest are in the age range between $20-30$ years $(15 \%)$. In terms of the highest education completed is Bachelor (64\%), Magister level from Law and Management education (33\%) then Doctoral Education as much as 3\% of the total respondents. The highest doctoral-level education came from sample members with the highest rank in this study (e.g., AKBP, KOMPOL, KOMBES); Magister level generally came from middle and high school and undergraduate positions from lower to middle place (e.g., BRIGPOL, BRIPKA, AIPDA). Based on the marital status, $96 \%$ of the sample were married, the remaining $4 \%$ were single or never married (divorced).

\subsection{Measurement}

The research model and approach use quantitative explanatory methods by selecting structural equation modeling (SEM) as the basis for statistical analysis to determine the influence and relationship between 
variables whose data is processed using AMOS software. Then data collection uses a survey with a Likert scale $(1=$ strongly disagree, $2=$ disagree, $3=$ disagree, $4=$ neutral, $5=$ somewhat agree, $6=$ agree, $7=$ strongly agree). There are four dependent and independent variables (e.g., TrainingEffectiveness, soft-skill competence, Employee-Creativity, Team-Performance). Variable Training-Effectiveness (TE) refers to the study (e.g., Perdue et al., 2002; Wilson et al., 2002) with three main questions as variable items e.g., additional knowledge (AK); ability to remember (AR); ability to practice (AP). The variable Soft-Skill Competence (SC) refers to the study (e.g., Spencer \& Spencer, 1993; Chou et al., 2010; Dwi Riyanti et al., 2016; Salina Daud et al., 2012) with five question items e.g., Searching for information (SI); Orientation on efficiency (OE); Systematic planning (SP); Problem solving (PS); Persuasive ability (PA). The variable Employee-Creativity (EC) refers to study (e.g., Beheshtifar \& Zare, 2013; M., 2008) which consists of four question items e.g., creativity-related skills (CRS); Encounter to ambiguity conditions (CAC); Locus of Control (LOC); Need for achievement (NA). The Team-Performance (TP) variable as the dependent variable refers to the study (Hwang, 2018) and is measured by five question items e.g., contributing to teamwork (CTW); Interacting with teammates (ITs); Keeping team on track (KT); Expectation quality (EQ); having relevant knowledge-skill-abilities (HR). The conceptual framework is illustrated in Figure 1 with
Training-Effectiveness (TE) as an exogenous variable. The Soft-Skill Competence (SC) and Employee-Creativity (EC) variables are mediator variables, and the Team-Performance (TP) variable as endogenous variables.

The stages in parametric statistical testing, mostly using AMOS have several test steps. The first step is the extraction of questionnaires in the form of a Likert scale included in the SPSS application to test the normality of data using the Kolmogorov-Smirnov residual method with criteria (Asymp. Sig > 0.05) apart from that, in SPSS, validity testing is also carried out using the Spearman-correlation method, and testing the reliability value. In the first stage of testing of SPSS, the normality value was $0.12>0.05$, so that the normality test was concluded to be normally distributed. We also test the validity and reliability of SPSS so that the assessment of validity and reliability when data is migrated to AMOS is of maximum value and obtains an ideal model. Therefore, the results of testing the validity and reliability via SPSS, the data testing results are declared valid in the range of 0.01 level and reliable above 0.70 . The second step is to export the original data from SPSS to AMOS. This second stage is to determine the estimated expected value, standard error (SE). Critical Ratio (CR). Besides, it is still in the step of testing the classic assumptions in AMOS, the Goodness of fit Model (GoF) criteria by measuring the expected small Chi-Square value; RMSEA $<0.08$; GFI $>0.90$; AGFI $>0.90$; Degree of Freedom $>2.0$; CFI and TLI $>0.95$.

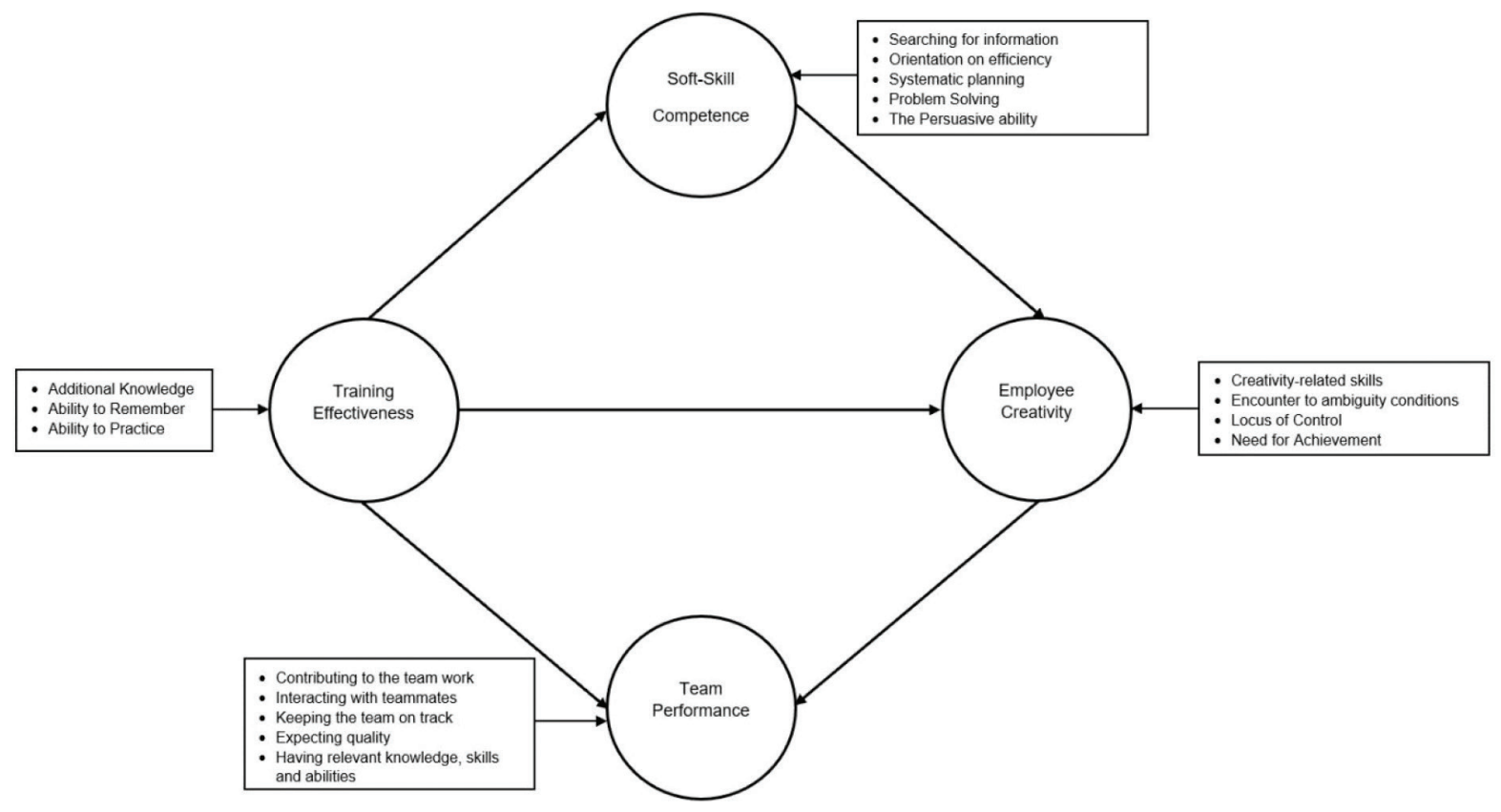

Figure 1: Conceptual Framework 
Table 1: Variables / Item Measurement

\begin{tabular}{|c|c|c|}
\hline Variable & Item & Indicators \\
\hline \multirow{3}{*}{$\begin{array}{l}\text { Training- } \\
\text { Effectiveness }\end{array}$} & additional knowledge & $\begin{array}{l}\text { - Have additional knowledge after attending training } \\
\text { - Have other work skills after training }\end{array}$ \\
\hline & ability to remember & $\begin{array}{l}\text { - Ability to remember during training } \\
\text { - Ability to understand during training }\end{array}$ \\
\hline & ability to practice & $\begin{array}{l}\text { - The ability to apply the results of training in work } \\
\text { - Ability to put the effects of training into work }\end{array}$ \\
\hline \multirow{5}{*}{ Soft Competence } & searching for information & $\begin{array}{l}\text { - The desire to seek and share information to increase } \\
\text { knowledge }\end{array}$ \\
\hline & orientation on efficiency & - Simple workability and prioritizes work efficiency \\
\hline & systematic planning & - Ability to do systematic planning in work \\
\hline & problem solving & $\begin{array}{l}\text { - Responsive and alert to problems and able to find solutions } \\
\text { faced by the work team }\end{array}$ \\
\hline & the persuasive ability & $\begin{array}{l}\text { - Ability to communicate ideas and convince others of my } \\
\text { ideas }\end{array}$ \\
\hline \multirow{4}{*}{ Employee-Creativity } & creativity-related skills & $\begin{array}{l}\text { The desire to improve skills and think of new ideas so that } \\
\text { the work process becomes more concise and accurate }\end{array}$ \\
\hline & encounter to ambiguity conditions & $\begin{array}{l}\text { - Ability to make decisions and ideal solutions from difficult } \\
\text { situations }\end{array}$ \\
\hline & locus of control & - Ability to anticipate work barriers and self-confidence \\
\hline & need for achievement & - Trying to do my best to get the best at work \\
\hline \multirow{5}{*}{ Team-Performance } & contributing to the team's work & - Always try to contribute to teamwork \\
\hline & interacting with teammates & - Always try to interact with teammates \\
\hline & keeping the team on track & - Always try to keep the team on track \\
\hline & expecting quality & - Always work with a team and expect quality work \\
\hline & $\begin{array}{l}\text { having relevant knowledge, skills, } \\
\text { and abilities }\end{array}$ & $\begin{array}{l}\text { - The desire to have knowledge, skills, and abilities relevant } \\
\text { to teamwork }\end{array}$ \\
\hline
\end{tabular}

After the second stage fulfills the requirements, the final step is hypothesis testing, namely by testing the T-Test with criteria $>1.98$ with a significance value $<0.05$ as described in Table 3. In connection with the data analysis testing phase and the detailed explanation of variable measurement items, we summarize in Table 2.

\section{Results and Discussion}

\subsection{Results}

Table 2 describes the statistical testing results, where the overall P-value of variables and items is significant $<0.01$. The critical ratio item value, on average, is above 6,609 . The standard error value (SE) is also minimal when compared with the obtained estimate value. In the standardized estimate section for variable items, in general, it is above 0.60 ; this explains that the item intervention on the standardized estimate value is in a high span. In connection with this, several items were removed from the test, such as the Searching for information (SI) item for the Training-Effectiveness (TE) variable; item Need for achievement (NA) for the variable EmployeeCreativity (EC); and two items in Team-Performance (TP), namely Keeping the team on track (KT), Having relevant knowledge, skills and abilities (HR). The deleted items indicated that the validity value and the estimated standard were not fulfilled.

The dominant item component that forms the TrainingEffectiveness (TE) variable is the Ability to Practice (AP) items. AP has the highest standard estimate value, among other items in the TE variable. Furthermore, the dominant soft-skill competence (SC) variable was formed by the Systematic planning (SP) item with a standard estimate value of 0.882 . The dominant Employee-Creativity (EC) variable is started by the Creativity-related skills (CRs) item, and the Contribution predominantly creates the Team-Performance (TP) variable to teamwork (CTW) item. 
Table 2: Statistical Result

\begin{tabular}{|c|c|c|c|c|c|c|}
\hline Variables & Item & $\begin{array}{l}\text { Standardized } \\
\text { Estimate }\end{array}$ & Estimate & $\begin{array}{l}\text { Standard } \\
\text { Error (S.E) }\end{array}$ & $\begin{array}{c}\text { Critical } \\
\text { Ratio (CR) }\end{array}$ & P-Value \\
\hline \multirow{3}{*}{$\begin{array}{l}\text { Training- } \\
\text { Effectiveness } \\
\text { (TE) }\end{array}$} & Additional knowledge & 0.771 & 0.955 & 0.084 & 11.320 & $* * *$ \\
\hline & Ability to remember & 0.759 & 1.240 & 0.113 & 11.007 & $* * *$ \\
\hline & Ability to practice & 0.785 & 1.000 & - & - & $* * *$ \\
\hline \multirow{5}{*}{$\begin{array}{l}\text { Soft-Skill } \\
\text { Competence } \\
\text { (SC) }\end{array}$} & Searching for information & Deleted Item & - & - & - & - \\
\hline & Orientation on efficiency & 0,820 & 1,000 & - & - & $* \star *$ \\
\hline & Systematic planning & 0,882 & 1,253 & 0,081 & 15,382 & $* * *$ \\
\hline & Problem solving & 0,818 & 0,979 & 0,071 & 13,710 & $* * *$ \\
\hline & The persuasive ability & 0,852 & 1,047 & 0,073 & 14,372 & $* * *$ \\
\hline \multirow{4}{*}{$\begin{array}{l}\text { Employee- } \\
\text { Creativity (EC) }\end{array}$} & Creativity-related skills & 0,914 & 1,027 & 0,064 & 15,956 & $* * *$ \\
\hline & $\begin{array}{l}\text { Encounter to ambiguity } \\
\text { conditions }\end{array}$ & 0,800 & 1,158 & 0,089 & 12,948 & $* * *$ \\
\hline & Locus of control & 0,812 & 1,000 & - & - & $* * *$ \\
\hline & Need for achievement & Deleted Item & - & - & - & - \\
\hline \multirow{5}{*}{$\begin{array}{l}\text { Team- } \\
\text { Performance } \\
\text { (TP) }\end{array}$} & Contributing to the team's work & 0,870 & 1,243 & 0,084 & 14,799 & $* * *$ \\
\hline & Interacting with teammates & 0,855 & 1,000 & - & - & $* * *$ \\
\hline & Keeping the team on track & Deleted Item & - & - & - & - \\
\hline & Expecting quality & 0,735 & 0,963 & 0,080 & 12,000 & $* * *$ \\
\hline & $\begin{array}{l}\text { Having relevant knowledge, } \\
\text { skills, and abilities }\end{array}$ & Deleted Item & - & - & - & - \\
\hline \multicolumn{2}{|c|}{ Soft-Skill Competence $\leftarrow$ Training-Effectiveness } & 0,861 & 0,436 & 0,040 & 10,817 & $* * *$ \\
\hline \multicolumn{2}{|c|}{ Employee-Creativity $\leftarrow$ Soft-Skill Competence } & 0,528 & 0,577 & 0,128 & 4,513 & $* * *$ \\
\hline \multicolumn{2}{|c|}{ Employee-Creativity $\leftarrow$ Training-Effectiveness } & 0,464 & 0,257 & 0,064 & 3,993 & $* * *$ \\
\hline \multicolumn{2}{|c|}{ Team-Performance $\leftarrow$ Employee-Creativity } & 0,159 & 0,150 & 0,224 & 0,671 & 0,502 \\
\hline \multicolumn{2}{|c|}{ Team-Performance $\leftarrow$ Training-Effectiveness } & 0,724 & 0,379 & 0,130 & 2,918 & 0,004 \\
\hline \multicolumn{2}{|c|}{ Model Fit Testing } & \multicolumn{3}{|c|}{ Value } & \multicolumn{2}{|c|}{ Info } \\
\hline \multicolumn{2}{|c|}{ Normality Test (Kolmogorov-Smirnov Test) } & \multicolumn{3}{|c|}{$0.12>0.05$} & \multicolumn{2}{|c|}{ Normal / Parametric } \\
\hline \multicolumn{2}{|l|}{ Chi-Square } & \multicolumn{3}{|c|}{153,770} & \multicolumn{2}{|c|}{ Ideal } \\
\hline \multicolumn{2}{|c|}{ Degree of Freedom } & \multicolumn{3}{|c|}{60} & \multicolumn{2}{|c|}{ Ideal } \\
\hline \multicolumn{2}{|l|}{ CMIN } & \multicolumn{3}{|c|}{2.563} & \multicolumn{2}{|c|}{ Fit } \\
\hline \multicolumn{2}{|l|}{ GFI } & \multicolumn{3}{|c|}{$0.898<0.90$} & \multicolumn{2}{|c|}{ Ideal } \\
\hline \multicolumn{2}{|l|}{ AGFI } & \multicolumn{3}{|c|}{$0.846>0.80$} & $\mathrm{~F}$ & \\
\hline TLI & & & $0.941>0.90$ & & $\mathrm{~F}$ & \\
\hline CFI & & & $0.945>0.90$ & & $\mathrm{~F}$ & \\
\hline RMSEA & & & .08 equal 0.0 & & Ide & \\
\hline
\end{tabular}

Note: ${ }^{* *}($ Significant at Level $\mathrm{P}<0.01)$. 


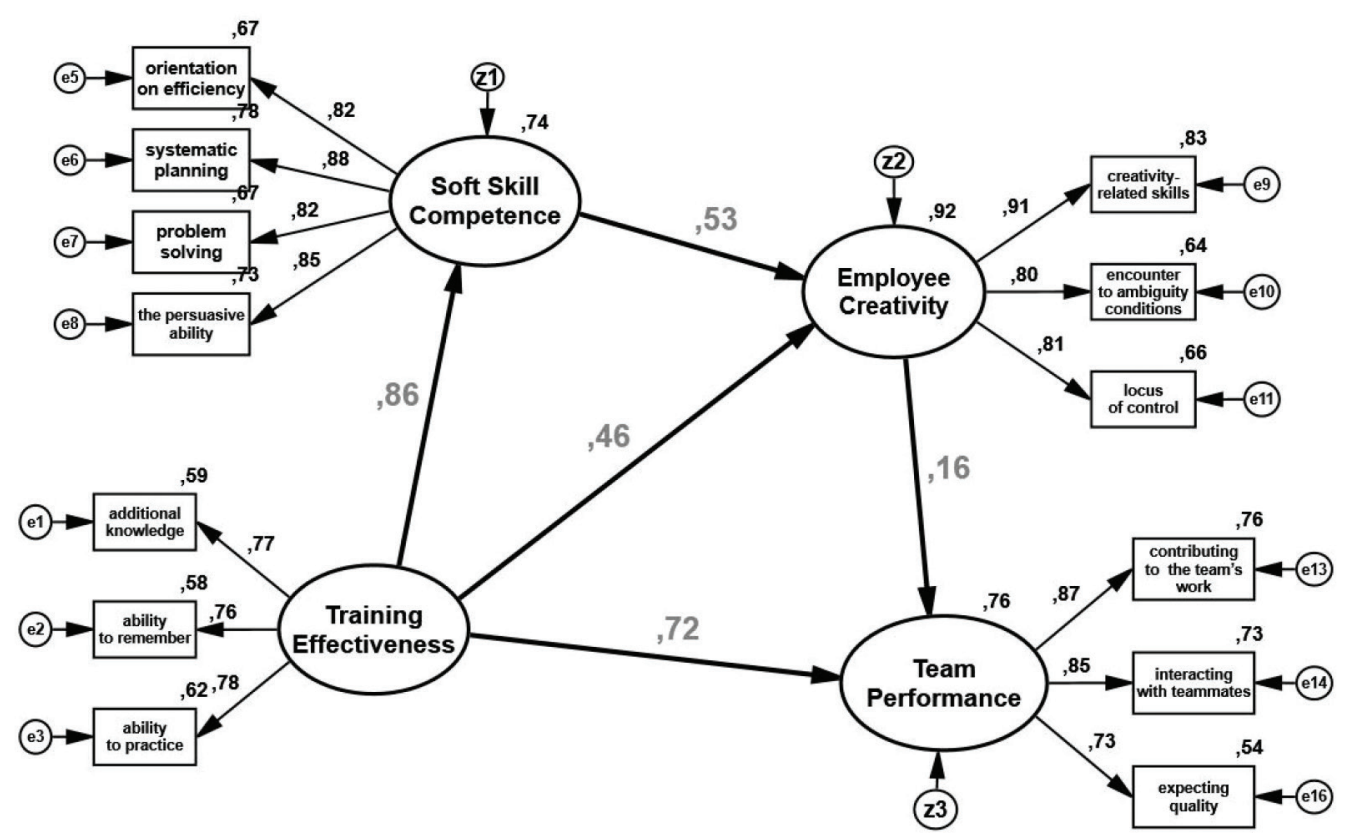

Figure 2: Structural Equation Model

Table 3: Regression Result

\begin{tabular}{|l|c|c|c|c|}
\hline Hypothesis & Estimate & C.R & p-Value & Info \\
\hline Training-Effectiveness (TE) $\rightarrow$ Soft-Skill competence (SC), & 0.861 & 10.817 & $0.000<0.01$ & Support \\
\hline Training-Effectiveness (TE) $\rightarrow$ Employee-Creativity (EC) & 0.464 & 3.993 & $0.000<0.01$ & Support \\
\hline Training-Effectiveness (TE) $\rightarrow$ Team-Performance (TP) & 0.724 & 2.918 & $0.004<0.05$ & Support \\
\hline Soft-Skill Competence (SC) $\rightarrow$ Employee-Creativity (EC) & 0.528 & 4.513 & $0.000<0.01$ & Support \\
\hline Employee-Creativity (EC) $\rightarrow$ Team-Performance (TP) & 0.156 & 0.671 & $0.502>0.05$ & Not Support \\
\hline
\end{tabular}

Apart from that, the explanation in Table 2 also illustrates that the feasibility test of the model has met the requirements for Structural Equation Modeling. As in the normality test, which states in the Kolmogorov-Smirnov method, Asymp. Sig $=0.12>0.05$ so that the value states that the normality assumption has been fulfilled and is feasible to be tested according to the allotment of the AMOS statistical application, which requires data that must be normally distributed. Then the Goodness of Fit model described by the values of Chi-Square, DF, GFI, TLI, AGFI, and RMSEA also shows the achievement of the ideal value, and some of the model eligibility tests state that the model in this study is Fit. The Structural Model is described in Figure 2.

The first and the second stages in the testing process have been carried out. Then the final stage is testing the hypothesis through the influence test through the Structural Equation model by comparing the T-Statistical value to the P-Value value with a significance coefficient of $<0.05$. Hypothesis testing described in Table 3 shows that the relationship that explains between the variables Training-Effectiveness (TE) on Soft-Skill competence (SC), Training-Effectiveness (TE) on Employee-Creativity (EC), Training-Effectiveness (TE) on Team-Performance (TP) and Soft-skill Competence (SC) on Employee-Creativity (EC) Overall Hypotheses H1 - H4 have a positive and significant effect with a significance value $<0.05$. While the fifth hypothesis is the relationship between the Employee-Creativity (EC) variable on TeamPerformance (TP) has no significant effect $(\mathrm{CR}=0.671$, $\mathrm{Sig}=0.502>0.05)$.

\subsection{Discussion}

The test demonstration results show that TrainingEffectiveness (TE) has a direct positive impact on other variables. This indicates that practical training can create competency improvements for soft skills that are in line with the research results (Sahinidis \& Bouris, 2008). TrainingEffectiveness provides the potential for internal members of the organization to have the opportunity to have additional knowledge through the results of training simulation practice 
so that optimal experience during the training process will also have an impact on work efficiency and effectiveness, both in terms of time use, and more optimal work output. Apart from that, the effect of Training-Effectiveness in the soft-skill dimension of competence states that excess experience also affects systematic decision making. Starting from the work planning process, communicating ideas, and work processes to find work steps that are more practical and easy to use. Training can be said to be effective when it meets several criteria as the output of training results, such as additional knowledge, ability to remember, and ability to practice. Apart from that, the test demonstration also shows a strong relationship and influence that associates the role of Training-Effectiveness on creative employees. Rationally when the training process is applied effectively, it will undoubtedly result in a creative thinking process that can also be claimed as soft skills. The continuous training process as a means of adapting to the actual work process can lead the internal organization (human resources) to take an attitude towards decisions carefully when faced with a dilemma. Therefore the different role of locus of control is also the main thing to bridge this.

The world of work requires creativity to survive in various uncertain conditions in competition, including competition between internal organizations. Creativity is an innate characteristic that every human being has. Humans' task and role as an inner part of the organization are to maintain rhythm and hone creativity to not blunt. Various basic principles of inner creativity were used in this study and several items were found to be valid and reliable, namely the ability to encounter ambiguity conditions, locus of control or internal self-control, and need for achievement. Therefore, the availability of resources and effective training is beneficial for organizations to realize creative ideas. For realization of creative ideas, it is important to provide and support a conducive work environment and give practical training, it helps the internal organization to think creatively. Causality between Training-Effectiveness and creativity can be manifested as long as vital communication is displayed. Essential communication is required so that the human resources in the organization can compete in achieving positive achievements. Essential communication means the ability to communicate ideas, beliefs, and experiences that were absorbed during the training process. Therefore, the organization's internal freedom in work processes also contributes in encouraging creativity which leads to human resources becoming competent professionals. Soft-skills also have a positive and significant effect on EmployeeCreativity; this means that the better competence in the soft skills, the more creativity will occur. In line with the study conducted by George \& Zhou (2007) state human resources who can do systematic planning can solve problems. The ability to negotiate will help an employee calm down at work where a good mood is a factor that can encourage an employee's creativity to increase.

This study also shows results that are not significantly associated, namely the relationship that describes the role of Employee-Creativity on Team-Performance. If in various previous studies, there was a positive correlation (e.g., Beheshtifar \& Zare, 2013; M., 2008; Hwang, 2018) between Employee-Creativity and Team-Performance, but in this study, there are conflicting results. Considering that this study's subject is the police service, the assumption does not significantly affect the relationship due to organizational characteristics. In various private organizations, employee creativity is undoubtedly supported by the freedom of resources. This means that the freer an employee is in exploring his / her talents and abilities, the better the company's performance will be; However, in the governmental organization sector, the freedom factor is bound and regulated in the primary organizational legislation and employees are better measures in police organizations, team contributions, and team interaction are mandatory and known as state servants so that the meaning of creativity is a reasonable and controlled restriction of freedom. Likewise, team performance has been regulated as a working mechanism. These contradictory results lead to rational syllogism, which assumes that an effective training process will have a substantial impact on improving soft-skills. Good soft skills that is a result of practical training which produces good, mature, and optimal creativity. However, differences in organization's structural characteristics, vision, and mission are fundamental factors that come together to define creativity. This study underlines that employee creativity does not have a significant association with Team-Performance.

Theoretically, this study contributes positively to the development of human capital management theory (e.g., Bontis et al., 2007; Mention \& Bontis, 2012) This study emphasizes that employees are part of intangible assets to improve organizational performance. As for its contribution to improving performance, of course, through several motivating aspects, practical training targeted towards increasing soft-skills and creativity is a fundamental need and it not only contributes to the growth of the organization but also provides personal feedback for self-development. Internal organization, namely training leads to orientation so that human resources can think critically, and are oriented towards efficiency, work systematically and measuredly, solve problems objectively and inclusively, and enhance personal abilities.

\section{Conclusions}

It has been constructed in the literature review that Training-Effectiveness before increasing Team-Performance first increases soft skill competence then increases 
Akmal UMAR, Hasmin TAMSAH, M. MATTALATTA, B. BAHARUDDIN, Abdul LATIEF R /

Journal of Asian Finance, Economics and Business Vol 7 No 11 (2020) 1021-1031

Employee-Creativity then improves team performance. The results showed that Training-Effectiveness could directly encourage growth in soft skills competence, employee creativity, and Team-Performance. Furthermore, TrainingEffectiveness can improve soft-skill competence so that its contribution to Employee-Creativity is more significant than the contribution of Training-Effectiveness to EmployeeCreativity. Meanwhile, the contribution of EmployeeCreativity is not that strong for Team-Performance compared to the contribution of Training-Effectiveness to Team-Performance. However, this empirical evidence can provide an answer to the missing link perceived in this study. This research can illustrate those police officers who have attended practical training can simultaneously increase their soft skills, competence, creativity, and Team-Performance. However, at the same time, creativity cannot push TeamPerformance better as Training-Effectiveness towards Team-Performance can do. Further research is needed with an expanded sample to provide maximum results, especially how the relationship between creativity and Team-Performance is required. Furthermore, the strength of the indirect relationship between Training-Effectiveness and Team-Performance through soft skills competence and Employee-Creativity is not discussed in detail in this study.

\section{References}

Aboyassin, N. A., \& Sultan, M. A. F. (2017). The Role of Human Resources Training in Improving the Employee's Performance: Applied Study in the Five Stars Hotels in Jordan. International Journal of Business Administration, 8(5), 46. https://doi. org/10.5430/ijba.v8n5p46

Akob, M., Arianty, R., \& Putra, A. H. P. K. (2020). The Mediating Role of Distribution Kahn's Engagement: An Empirical Evidence of Salesforce in Indonesia. Journal of Asian Finance, Economics and Business, 7(2), 249-260. https://doi. org/10.13106/jafeb.2020.vol7.no2.249

Almendarez, L. (2013). Human Capital Theory: Implications for Educational Development in Belize and the Caribbean. Caribbean Quarterly, 59(3-4), 21-33. https://doi.org/10.1080/ 00086495.2013 .11672495

Appiah, B. (2010). The impact of training on employment performance: a case study of HFC Bank (Ghana) Limited (Issue April). Ashesi University College.

Arfah, A., \& Putra, A. H. P. K. (2019). Analysis of Productivity and Distribution of Female Workers in FB's Industries. Journal of Distribution Science, 17(3), 31-39. https://doi.org/10.15722/ jds.17.3.201903.31

Asfaw, A. M., Argaw, M. D., \& Bayissa, L. (2015). The Impact of Training and Development on Employee Performance and Effectiveness: A Case Study of District Five Administration Office, Bole Sub-City, Addis Ababa, Ethiopia. Journal of Human Resource and Sustainability Studies, 3(3), 188-202. https://doi.org/http://dx.doi.org/10.4236/jhrss.2015.34025
Beersma, B., Hollenbeck, J. R., Humphrey, S. E., Moon, H., Conlon, D. E., \& Ilgen, D. R. (2003). Cooperation, competition, and team performance: Toward a contingency approach. Academy of Management Journal, 46(5), 572-590. https://doi. org $/ 10.2307 / 30040650$

Beheshtifar, M., \& Zare, E. (2013). Employee Creativity: A compulsory Factor in Organizations. Interdisciplinary Journal of Contemporary Research in Business, 5(2), 242-247.

Blickensderfer, E., Cannon-Bowers, J. A., \& Salas, E. (2004). Cross-training and team performance. Making Decisions under Stress: Implications for Individual and Team Training., 299-311. https://doi.org/10.1037/10278-011

Bontis, N., Seleim, A., \& Ashour, A. (2007). Human capital and organizational performance: A study of Egyptian software companies. Management Decision, 45(4), 789-801. https://doi. org/10.1108/00251740710746033

Chou, C. M., Shen, C. H., Hsiao, H. C., \& Chen, S. C. (2010). A study on constructing entrepreneurial competence indicators for business department students of vocational and technical colleges in Taiwan. World Transactions on Engineering and Technology Education, 8(3), 316-320.

Dong, L. N. T., \& Phuong, N. N. D. (2018). Organizational justice, job satisfaction and organizational citizenship behavior in higher education institutions: A research proposition in Vietnam. Journal of Asian Finance, Economics and Business, 5(3), 113119. https://doi.org/10.13106/jafeb.2018.vol5.no3.113

Dwi Riyanti, B. P., Sandroto, C. W., \& Warmiyati D.W, M. T. (2016). Soft Skill Competencies, Hard Skill Competencies, and Intention to Become Entrepreneur of Vocational Graduates. International Research Journal of Business Studies, 9(2), 119132. https://doi.org/10.21632/irjbs.9.2.119-132

Edwards, B. D., Day, E. A., Arthur, W., \& Bell, S. T. (2006). Relationships among team ability composition, team mental models, and team performance. Journal of Applied Psychology, 91(3), 727-736. https://doi.org/10.1037/0021-9010.91.3.727

Firman, A., Mustapa, Z., Ilyas, G. B., \& Putra, A. H. P. K. (2020). Relationship of TQM on managerial perfomance: Evidence from property sector in Indonesia. Journal of Distribution Science (Vol. 18, Issue 1, pp. 47-57). https://doi.org/10.15722/ jds.18.01.20201.47

Firman, A., Putra, A. H. P. K., Mustapa, Z., Ilyas, G. B., \& Karim, K. (2020). Re-conceptualization of Business Model for Marketing Nowadays: Theory and Implications. Journal of Asian Finance, Economics and Business, 7(7), 279-291. https://doi.org/10.13106/jafeb.2020.vol7.no7.279

Fix, B. (2018). The Trouble with Human Capital Theory. RealWorld Economics Review, 86, 15-32. https://doi.org/10.31235/ osf.io/ax6k7

George, J. M., \& Zhou, J. (2007). Dual Tuning in a Supportive Context: Joint Contributions of Positive Mood, Negative Mood, and Supervisory Behaviors to Employee Creativity. Academy of Management Journal, 50(3), 605-622. https://doi. org/10.1.1.551.9757 
Haerani, S., Sumardi, Hakim, W., Hartini, \& Putra, A. H. P. K. (2020). Structural Model of Developing Human Resources Performance: Empirical Study of Indonesia States Owned Enterprises. Journal of Asian Finance, Economics and Business, 7(3), 211-221. https://doi.org/10.13106/jafeb.2020. vol7.no3.211

Hecht, T. D., \& Allen, N. J. (2009). Team mental models and team performance : A field study of the effects of team mental model similarity and accuracy. Journal of Organizational Behavior, 30(October 2004), 839-862.

Hendrawan, A., Sucahyawati, H., Cahyandi, K., \& Indriyani. (2018). Improving Team Performance With Organizational Learning and Knowledge Sharing. Borneo International Conference on Education and Social Sciences, July, 1-12.

Hwang, M. I. (2018). Relationship between teamwork and team performance: Experiences from an ERPsim competition. Journal of Information Systems Education, 29(3), 157-168.

Ikram, M., Abirami, M. J., \& Swaminathan, S. (2019). Effectiveness of Training on Competency Development. Galore International Journal of Health Sciences and Research, 4(2), 28-33.

Inn, T. C., Zailani, S., Ramayah, T., \& Fernando, Y. (2010). An investigation into the dimensions of training effectiveness on post training outcomes of quality management system. International Journal of Productivity and Quality Management, 5(2), 171-199. https://doi.org/10.1504/IJPQM.2010.030741

Jamshed, S., Nazri, M., \& Abu Bakar, R. (2018). The Effect of Knowledge Sharing on Team Performance through Lens of Team Culture. Oman Chapter of Arabian Journal of Business and Management Review, 7(3), 64-80. https://doi. org/10.12816/0049504

Joo, B. K. (Brian), McLean, G. N., \& Yang, B. (2013). Creativity and Human Resource Development: An Integrative Literature Review and a Conceptual Framework for Future Research. Human Resource Development Review, 12(4), 390-421. https:// doi.org/10.1177/1534484313481462

Juniper, D. (1996). Human resource and creativity. Work Study, 45(7), 15-22. https://doi.org/10.1108/00438029610150957

Kiliç, K. M., \& Güngör Aytar, F. A. (2017). The effect of social skills training on social skills in early childhood, the relationship between social skills and temperament. Egitim ve Bilim, 42(191), 185-204. https://doi.org/10.15390/EB.2017.7162

Laurens, S., \& Putra, A. H. P. K. (2020). Poverty Alleviation Efforts through MDG's and Economic Resources in Indonesia. Journal of Asian Finance, Economics and Business, 7(9), 755-767. https://doi.org/10.13106/jafeb.2020.vol7.no9.755

Lee, L., Rd, D., District, Y., City, T., \& Trade, I. (2012). the Influences of Antecedents on Employee Creativity and Employee Performance: A Meta-Analytic Review. Interdisciplinary Journal of Contemporary Research In Business, 4(2), 984-997.

Lestari, S. D., Leon, F. M., Widyastuti, S., Brabo, N. A., \& Putra, A. H. P. K. (2020). Antecedents and Consequences of Innovation and Business Strategy on Performance and Competitive Advantage of SMEs. Journal of Asian Finance, Economics and
Business, 7(6), 365-378. https://doi.org/10.13106/jafeb.2020. vol7.no6.365

Lewis, K. (2004). Knowledge and performance in knowledgeworker teams: A longitudinal study of transactive memory systems. Management Science, 50(11), 1519-1533. https://doi. org/10.1287/mnsc. 1040.0257

Liu, D., Gong, Y., Zhou, J., \& Huang, J. C. (2017). Human resource systems, employee creativity, and firm innovation: The moderating role of firm ownership. Academy of Management Journal, 60(3), 1164-1188. https://doi.org/10.5465/ amj.2015.0230

Mansur, D. M., Sule, E. T., Kartini, D., Oesman, Y. M., Putra, A. H. P. K., \& Chamidah, N. (2019). Moderating of the role of technology theory to the existence of consumer behavior on e-commerce. Journal of Distribution Science, 17(7), 15-25.

Mappamiring, M., Akob, M., \& Putra, A. H. P. K. (2020). What Millennial Workers Want? Turnover or Intention to Stay in Company. Journal of Asian Finance, Economics and Business, 7(5), 237-248. https://doi.org/10.13106/jafeb.2020.vol7. no5.237

Marginson, S. (2019). Limitations of human capital theory. Studies in Higher Education, 44(2), 287-301. https://doi.org/10.1080/0 3075079.2017.1359823

Marks, M. A., Sabella, M. J., Burke, C. S., \& Zaccaro, S. J. (2002). The impact of cross-training on team effectiveness. The Journal of Applied Psychology, 87(1), 3-13. https://doi. org/10.1037/0021-9010.87.1.3

Mayo, A. (2000). The role of employee development in the growth of intellectual capital. Personnel Review, 29(4), 521-533. https://doi.org/10.1108/00483480010296311

Meiyani, E., \& Putra, A. H. P. K. (2019). The relationship between Islamic leadership on employee engagement distribution in FMCG industry: Anthropology business review. Journal of Distribution Science, 17(5), 19-28.

Mention, A., \& Bontis, N. (2012). Intellectual capital and performance within the banking sector of Luxembourg and Belgium. https://doi.org/10.1108/14691931311323896

Neyestani, B. (2014). Impact of Training on Employee's Performance and Productivity in Construction Industry. SSRN Electronic Journal, UC Berkeley Previously Published Works. https://doi.org/10.2139/ssrn.2961057

Peeters, M. A. G., Van Tuijl, H. F. J. M., Rutte, C. G., \& Reymen, I. M. M. J. (2006). Personality and team performance: A metaanalysis. European Journal of Personality, 20(5), 377-396. https://doi.org/10.1002/per.588

Perdue, J., Ninemeier, J. D., \& Woods, R. H. (2002). Training methods for specific objectives: Preferences of managers in private clubs. International Journal of Contemporary Hospitality Management, 14(3), 114-119. https://doi. org/10.1108/09596110210424402

Qureshi, M. (2016). Research Issues in Social Sciences The Impact of Employees' Creativity on the Performance of the Firm. Research Issues in Social Sciences, 1(May), 1-12. 
Akmal UMAR, Hasmin TAMSAH, M. MATTALATTA, B. BAHARUDDIN, Abdul LATIEF R /

Sahinidis, A. G., \& Bouris, J. (2008). Employee perceived training effectiveness relationship to employee attitudes. Journal of European Industrial Training. https://doi. org/10.1108/03090590810846575

Salas, E., Prince, C., Baker, D. P., \& Shrestha, L. (1995). Situation awareness in team performance: Implications for measurement and training. Human Factors, 37(1), 123-136. https://doi. org/10.1518/001872095779049525

Salas, E., DiazGranados, D., Klein, C., Burke, C. S., Stagl, K. C., Goodwin, G. F., \& Halpin, S. M. (2008). Does team training improve team performance? A meta-analysis. Human Factors: The Journal of the Human Factors and Ergonomics Society, 50(6), 903-933. https://doi.org/10.1518/001872008X375009

Salina D., Abidin, N., Sapuan, N. M., \& Rajadurai, J. (2012). Efficient human resource deployment technique in higher education: A standpoint from Malaysia. African Journal of Business Management, 6(25), 7533-7547. https://doi. org/10.5897/ajbm11.558

Salman, W. A., \& Hassan, Z. (2015). The impact of teamwork on employee performance. Internatinal Journal of Accounting, Business and Management, 4(1), 77-86. https://doi. org/10.13140/RG.2.1.4959.8804

Sangha, K. K., Gerritsen, R., \& Russell-Smith, J. (2019). Repurposing government expenditure for enhancing Indigenous well-being in Australia: A scenario analysis for a new paradigm. Economic Analysis and Policy, 63, 75-91. https://doi.org/10.1016/j.eap.2019.04.011

Scaduto, A., Lindsay, D., \& Chiaburu, D. S. (2008). Leader influences on training effectiveness: Motivation and outcome expectation processes. International Journal of Training and Development, 12(3), 158-170. https://doi.org/10.1111/j.14682419.2008.00303.x

Scott, G., Leritz,L.E., \& Mumford, M.D.(2004). The effectiveness of creativity training: A quantitative review. In Creativity Research Journal. https://doi.org/10.1080/10400410409534549
Spencer, L. M., \& Spencer, S. M. (1993). Competence at work. Canada: John Wiley \& Sons, Inc.

Surbaini, K. N. (2018). Training Effectiveness And Employee Performance In A Malaysian Government-Linked Company. 282-288. https://doi.org/10.15405/epsbs.2018.07.02.30

Swart, J., Mann, C., Brown, S., \& Price, A. (2005). Human Resource Development: Strategy and Tactics. Oxford, UK: Elsevier Butterworth-Heinemann Publications.

Tan, E. (2014). Human Capital Theory: A Holistic Criticism. Review of Educational Research, 84(3), 411-445. https://doi. org/10.3102/0034654314532696

Weidmann, B., \& Deming, D. (2020). Team Players: How Social Skills Improve Group Performance. Psychology Applied to Work: An Introduction to Industrial and Organizational Psychology, Tenth Edition Paul, 53(9), 1689-1699. https://doi. org/10.3386/w27071

Wilson, P. H., Strutton, D., \& Farris, M. T. (2002). Investigating the perceptual aspect of sales training. Journal of Personal Selling and Sales Management, 22(2), 77-86. https://doi.org/10.1080/ 08853134.2002 .10754296

Young Choi, S., Lee, H., \& Yoo, Y. (2010). The impact of information technology and transactive memory systems on knowledge sharing, application, and team performance: A field study. MIS Quarterly: Management Information Systems, 34(4), 833-854. https://doi.org/10.2307/25750708

Zamora, B. (2007). A New Discussion of the Human Capital Theory in the Methodology of Scientific Research Programmes. Instituto Valenciano de Investigaciones Económicas.

Zhou, J., \& Shalley, C. E. (2003). Research on Employee Creativity: A Critical Review and Directions for Future Research. Research in Personnel and Human Resources Management, 22, 165-217. https://doi.org/10.1016/S0742-7301(03)22004-1 